UDC 631.847.211:635.652.2

(C) 2017

D. Krutylo, Candidate of Biological Sciences

O. Nadkernychna, Doctor of Biological Sciences

Institute of Agricultural Microbiology and Agro-Industrial Production of NAAS

S. Ivaniuk, Candidate of Agricultural Sciences

Institute of Forage and Agriculture of Podillya of the NAAS

O. Kuts, Candidate of Agricultural Sciences

Institute of Vegetable and Melons, NAAS

\title{
EFFICIENCY OF BIOLOGICAL PREPARATIONS ON THE BASIS OF NEW STRAIN OF RHIZOBIUM PHASEOLI FB1 AT GROWING BEAN
}

The purpose. To study efficiency of biological preparations for bean on the basis of new strain of nodule bacteria Rhizobium phaseoli FB1. Methods. Microbiological, field and statistical. Results. In different soil-climatic conditions trials of biological preparations Rizobofit and Rizogumin are conducted at growing grain and kidney bean. It is determined that application of new strain of Rhizobium phaseoli of beans as the bioagent of microbial specimens ensures increase in yield of grain of bean for $11-32 \%$ in comparison with control. Conclusions. To increase productivity of bean it is offered to apply biological preparations Rizobofit and Rizogumin on the basis of highly effective strain of $R$. phaseoli FB1.

Key words: nodule bacteria, bean, Rizobofit, Rizogumin, Rhizobium phaseoli.

Common bean (Phaseolus vulgaris L.) is one of the most important legumes that is grown in many countries and is the second after soybean in acreage [1,12].

The main concentration of sowing of this crop is concentrated in Asia and South America. The main bean-producing countries are: India (9433 thousand ha), Brazil (4368 thousand ha), Mexico (1887 thousand ha) and China (1207 thousand ha) [2, $11]$.

Bean is a traditional culture for Ukraine. However, over the last $40-50$ years bean cultivation area in Ukraine has greatly decreased. Today, it accounts for only 20-30 thousand ha and is mainly concentrated on household plots in the private 
sector and at farms. The results of the research of domestic breeders on the creation of new varieties of beans, suitable for direct harvesting, give confidence that in the near future the cultivation area of this important crop will gradually increase in Ukraine. Before the war in the previous century bean was grown on the area of 136 thousand ha in Ukraine $[1,5]$.

Despite the prospects of expanding the range of bean varieties, nitrogen fixing potential of this culture is not fully used. Environmentally safe way to increase bean productivity is pre-plant seed inoculation with bacteria of Rhizobium phaseoli species, which initiate the formation of nitrogen fixing nodules on plants roots [1, $6,9]$.

Given that bean has become a traditional culture for Ukraine in the course of time, local populations of bean rhizobia have formed in soils. These populations can be both the source of economically valuable strains and, on the other hand, they can act as competitors to strains-inoculants $[1,9]$. In this regard, topical is the search of competitive and highly effective strains of bean rhizobia that can be used to improve existing and create new microbial preparations.

In the previous years we have obtained and patented a new R. phaseoli FB1 strain which is an active symbiotic nitrogen fixer and positively affects plant production process $[9,10]$. This strain may be a potential bio-agent of biological preparations Ryzohumin and Ryzobofit for the improvement of legumes productivity developed at the Institute of Agricultural Microbiology and Agroindustrial Manufacture of NAAS.

Given the above, the purpose of our work was to study the efficacy of use of biological preparations Ryzobofit and Ryzohumin based on a new active R. phaseoli FB1 strain when growing common bean in different regions of Ukraine.

Materials and methods of the study. The efficiency of biological preparations developed at the Institute based on a new strain of rhizobia R. phaseoli FB1 was studied in field experiments with common bean during 20122014. Liquid and peat form of biological preparation Ryzobofit (TUU 
319.00494456-006-2002) and a new complex preparation Ryzohumin (TUU 24.100497360-003: 2007) were used. Except rhizobia Ryzohumin includes vermicompost components: plant growth regulators, humic acids, amino acids, vitamins, a small amount of macroelements, and trace elements in chelated form. The study was conducted both in the absence of nodule bacteria that can infect bean in the soil, and against the background of local populations of specific rhizobia different in density.

Field experiments in the conditions of Woodlands of Ukraine (research plot of the Institute of Agricultural Microbiology and Agroindustrial Manufacture of NAAS, Chernihiv) was carried out on leached black soil ( $\mathrm{pH}-6.0$; humus content - $3.5 \%$, easily hydrolyzed nitrogen (by Kornfild) - $95 \mathrm{mg}$, mobile forms of phosphorus $\left(\mathrm{P}_{2} \mathrm{O}_{5}\right)$ (by Kyrsanov) - $251 \mathrm{mg}$, exchangeable potassium $\left(\mathrm{K}_{2} \mathrm{O}\right)$ (by Kyrsanov) - $108 \mathrm{mg}$ per $1 \mathrm{~kg}$ ). Bean seeds of Shchedra variety was used in the experiments. Repetition - quadruple. Plot accounting area $-6 \mathrm{~m}^{2}$. Plot location randomized.

Field experiment in the conditions of central Forest Steppe of Ukraine (experimental farm "Bokhonytske" of the Institute for Feed and Agriculture of Podillia of NAAS, city of Vinnytsia) was conducted on gray forest soil ( $\mathrm{pH}-4.9$ 5.3; humus content (by Turin) - 1.8-2.1\%, easily hydrolyzed nitrogen (by Kornfild) - 72.0-90.0 mg $\mathrm{P}_{2} \mathrm{O}_{5}-100.0-120.0 \mathrm{mg}$ and $\mathrm{K}_{2} \mathrm{O}$ (by Chyrykov) - 130.0$140.0 \mathrm{mg}$ per $1 \mathrm{~kg}$ ). Bean of Halaktyka variety was cultivated. Repetition - three times. Plot accounting area $-25 \mathrm{~m}^{2}$. Plot location - randomized.

Field experiments on the study of influence of mineral fertilizers and biological preparations on common bean seed performance were conducted in the area of the Left Bank Forest Steppe of Ukraine (Institute of Vegetables and Gourds Farming of NAAS) on typical black soil ( $\mathrm{pH}-5.7$; humus content $-4.3 \%$, easily hydrolyzed nitrogen (by Kornfild) - 126.0-134.0 mg, mobile phosphorus - 136.0$144.0 \mathrm{mg}$ and exchangeable potassium (by Chyrykov) - 168.0-180.0 mg per $1 \mathrm{~kg}$ ). Seeds of Shakhynia bean variety were used. Repetition - quadruple. Plot accounting area $-14 \mathrm{~m}^{2}$. Plot location - one tier systemized. 
The activity of nitrogen fixation was determined by acetylene method in gas chromatograph "Chrom-4". The evaluation of chemical composition of bean seeds was performed by original methods [3, 7, 9]. Mathematical data processing was carried out by B.O. Dospekhov [4] and using Statistica 7.0 computer program.

Research results. The efficiency of microbial preparations for legumes depends primarily on their bio-agents - rhizobia strains. In previous years, using the method of analytical selection, we obtained a new promising bean rhizobia strain - R. phaseoli FB1 (IMB B-7319), which is an active symbiotic nitrogen fixer, characterized by high competitiveness relative to specific local inactive rhizobia strains [10] and may be a potential bio-agent for common bean preparations.

The effectiveness of two fundamentally different biological preparations Ryzobofit and Ryzohumin based on a new strain of $R$. phaseoli FB1 was studied in a series of field experiments in soil and climatic conditions of steppes and Woodlands of Ukraine.

Thus, while cultivating common bean on leached black soil (in Woodlands area) nodules were not formed on plant roots of control variant (without treatment with biological preparations), indicating the absence of specific bean rhizobia in soil (table 1).

1. The number and mass of nodules on bean roots of Shchedra variety at inoculation with biological preparations based on R.phaseoli FB1 (field experiments, average for 2013-2014)

\begin{tabular}{|l|c|c|c|c|}
\hline \multirow{2}{*}{\begin{tabular}{c}
\multirow{2}{*}{$\begin{array}{c}\text { Variants of the } \\
\text { experiments }\end{array}$} \\
\cline { 2 - 5 }
\end{tabular}} & \multicolumn{2}{|c|}{$\begin{array}{c}\text { Amount of } \\
\text { nodules, pieces/plant }\end{array}$} & \multicolumn{2}{c|}{$\begin{array}{c}\text { Weight of nodules, } \\
\text { gram/plant }\end{array}$} \\
\hline $\begin{array}{l}\text { Without inoculation } \\
\text { (control sample) }\end{array}$ & 0 & 0 & 0 & 0 \\
\hline $\begin{array}{l}\text { Inoculation with Ryzobofit } \\
\text { (liquid form) }\end{array}$ & 8.63 & 19.19 & 0.12 & 0.21 \\
\hline $\begin{array}{l}\text { Inoculation with Ryzobofit } \\
\text { (peat form) }\end{array}$ & 8.38 & 18.82 & 0.18 & 0.23 \\
\hline $\begin{array}{l}\text { Inoculation with Ryzohumin } \\
\text { (liquid for) }\end{array}$ & 8.76 & 27.82 & 0.17 & 0.24 \\
\hline
\end{tabular}




\begin{tabular}{|l|c|c|c|c|}
\hline $\begin{array}{l}\text { Inoculation with Ryzohumin } \\
\text { (peat form) }\end{array}$ & 9.50 & 28.13 & 0.17 & 0.29 \\
\hline
\end{tabular}

In flowering stage the number of nitrogen fixing nodules in versions using Ryzobofit and Ryzohumin was small and ranged on average within 8-10 units per plant during two years. Only in the stage of beans filling their number increased significantly and amounted to 19-28 units per plant. As a whole, complex preparation Ryzohumin based on a new $R$. phaseoli FB1 strain helped to create significantly greater (1.4-1.5 times) number of nodules compared to Ryzobofit.

An important indicator of symbiotic activity of rhizobia and legumes is not only the number of nodules, but their mass. Thus, after treatment of bean seeds with peat form of Ryzobofit and both forms of Ryzohumin the mass of nodules was already significantly higher in the flowering stage compared to liquid form of Ryzobofit ( $0.17 \mathrm{~g} /$ plant to $0.12 \mathrm{~g} /$ plant). In the phase of beans filling the best by this indicator was the variant of treatment seeds with peat form of Ryzohumin (0.29 g/plant).

The highest level of molecular nitrogen fixation was also observed after the use of both forms of Ryzohumin and peat form of Ryzobofit (figure). It increased 2.4-2.8 times from flowering stage to beans filling stage. Maximum indicators of nitrogen fixation activity were recorded in the version using peat form of Ryzohumin (9.25 and $25.56 \mu \mathrm{g}$ N per plant per hour).

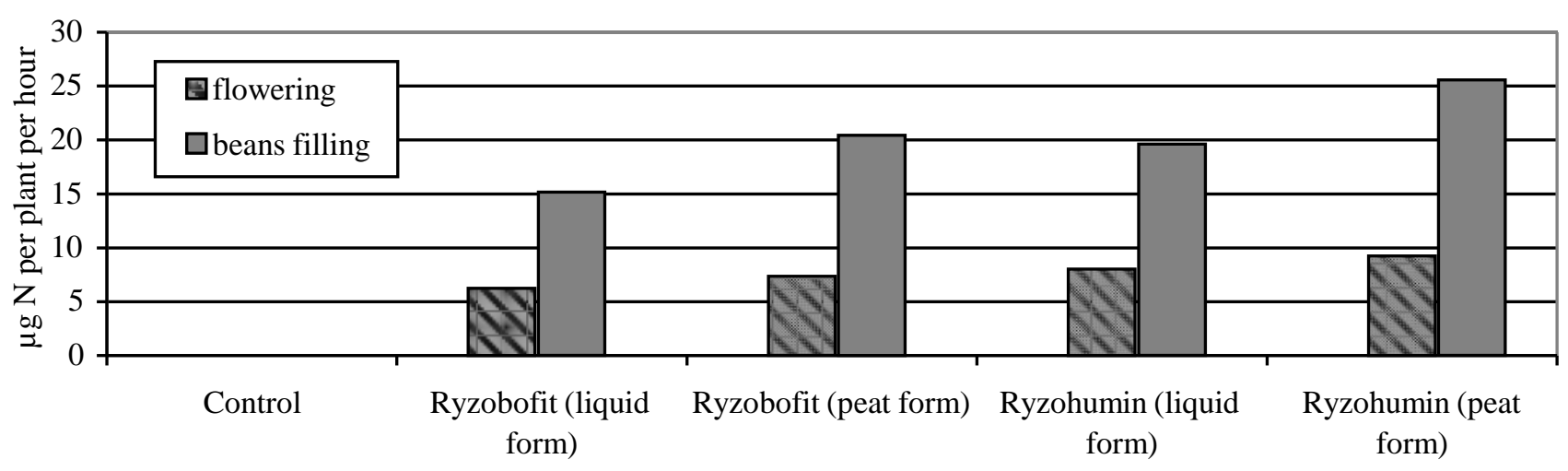


Nitrogenaze activity of bean nodules of Shchedra variety after seed treatment with biological preparations based on R.phaseoli FB1 (field experiments, average for 2013-2014.).

As a result of studies it was found that biological preparations Ryzobofit and Ryzohumin based on the proposed strain $R$. phaseoli FB1 provide stable productivity increase for beans of Shchedra variety by 16.9-29.2 \% compared to the control without inoculation (Table 2). Maximum level of productivity (3.05 t/ha) was observed during three years when using peat form of Ryzohumin. Using a new strain of rhizobia bean seeds quality indicators were improving - protein content increased by $12.5 \%$ and oil - by $17.4 \%$ relative to control.

In addition to positive effect on symbiotic performance, the use of new R. phaseoli FB1 strain, as bio-agent for preparations, significantly constrains the development of root rots, which is an important component of good yield. The effectiveness of strain protective action ranges from 26.8 to $36.7 \%$ [10].

2. Influence of bean seed of Shchedra variety treatment by various forms of biological preparations on plant productivity (field experiments, 2012-2014.)

\begin{tabular}{|l|c|c|c|c|c|c|}
\hline \multirow{2}{*}{$\begin{array}{c}\text { Variants of the } \\
\text { experiments }\end{array}$} & 2012 & 2013 & 2014 & Average & $\begin{array}{c}\text { tons/h } \\
\mathrm{a}\end{array}$ & $\%$ \\
\cline { 2 - 7 } & 1.93 & 2.94 & 2.22 & 2.36 & - & 100.0 \\
\hline $\begin{array}{l}\text { Without inoculation } \\
\text { (control sample) }\end{array}$ & 2.27 & 3.40 & 2.60 & 2.76 & +0.40 & 116.9 \\
\hline $\begin{array}{l}\text { Inoculation with Ryzobofit } \\
\text { (liquid form) }\end{array}$ & 2.34 & 3.57 & 2.85 & 2.92 & +0.56 & 123.7 \\
\hline $\begin{array}{l}\text { Inoculation with Ryzobofit } \\
\text { (peat form) }\end{array}$ & 2.28 & 3.61 & 2.79 & 2.89 & +0.53 & 122.5 \\
\hline $\begin{array}{l}\text { Inoculation with } \\
\text { Ryzohumin } \\
\text { (liquid for) }\end{array}$ & 2.38 & 3.79 & 2.98 & 3.05 & +0.69 & 129.2 \\
\hline $\begin{array}{l}\text { Inoculation with } \\
\text { Ryzohumin } \\
\text { (peat form) }\end{array}$ & 0.10 & 0.31 & 0.27 & & & \\
\hline LSD $_{05}$ & & & & & \\
\hline
\end{tabular}

Biopreparations based on $R$. phaseoli FB1 strain (peat form) were also tested in a field experiment in soil and climatic conditions of central steppes of Ukraine against the background of local population of bean rhizobia. 
These data show (Table 3) that, despite the presence of specific rhizobia in soil, biological preparations Ryzohumin and Ryzobofit contributed to significantincrease in bean yield of Halaktyka variety by 11.0-20.6 \% compared to control

(without inoculation).

3. Influence of inoculation with biological preparations on the productivity of bean of Halaktyka variety (field experiment, 2014)

\begin{tabular}{|l|c|c|c|}
\hline \multirow{2}{*}{$\begin{array}{c}\text { Variants of the } \\
\text { experiments }\end{array}$} & \multirow{2}{*}{ Yield, tons/ha } & \multicolumn{2}{c|}{ Increment, } \\
\cline { 3 - 4 } & & tons/ha & $\%$ \\
\hline $\begin{array}{l}\text { Without inoculation (control } \\
\text { sample) }\end{array}$ & 1.36 & - & 100.0 \\
\hline Inoculation with Ryzobofit & 1.64 & +0.28 & 120.6 \\
\hline Inoculation with Ryzohumin & 1.51 & +0.15 & 111.0 \\
\hline LSD $_{05}$ & 0.15 & & \\
\hline
\end{tabular}

The effectiveness of biological preparations Ryzobofit and Ryzohumin (peat form) in the system of green bean fertilizing was also studied during three years (2012-2014.) in the conditions of Left-bank Forest-Steppe of Ukraine (Institute of Vegetables and Gourds Farming of NAAS).

Studies showed that inoculation of bean seeds with microbial preparations on the background of phosphorus-potassium fertilizers contributed to significant increase of green bean yield relative to control (without inoculation and without fertilization) (Table 4). Thus, the use of complex preparation Ryzohumin based on a new $R$. phaseoli FB1 strain increased the productivity of Shakhynia variety bean by $0.86 \mathrm{t} / \mathrm{ha}$ that on average was at the level of productivity after fertilizing in the dose of $\mathrm{N}_{60} \mathrm{P}_{60} \mathrm{~K}_{60}$ during three years. Ryzobofit also contributed to bean yield increase to $3.14 \mathrm{t} / \mathrm{ha}$, which was close to the level of use of half-dose of mineral fertilizer $\mathrm{N}_{30} \mathrm{P}_{30} \mathrm{~K}_{30}$. These data suggest that the use of biological preparations based on a new strain of rhizobia enables reducing the introduction of mineral nitrogen fertilizers into the soil and obtaining high yields of green bean.

4. Green bean of Shakhynia variety yield depending on the use of mineral fertilizers and microbial preparations (field experiments, 2012-2014.)

Variants of the experiments Yield, tons/ha \begin{tabular}{|l|l|l|l|}
2012 & 2013 & 2014 & Average
\end{tabular} Increment, experinnents

\begin{tabular}{|l|l|l|l|l}
2012 & 2013 & 2014 & Average \\
\hline
\end{tabular}




\begin{tabular}{|l|c|c|c|c|c|c|}
\hline $\begin{array}{l}\text { Without inoculation } \\
\text { (control sample) }\end{array}$ & 2.02 & 3.14 & 2.90 & 2.69 & - & 100.0 \\
\hline
\end{tabular}

\begin{tabular}{|l|c|c|c|c|c|c|}
\hline $\mathrm{N}_{60} \mathrm{P}_{60} \mathrm{~K}_{60}$ broadcast & 3.24 & 3.90 & 3.50 & 3.55 & +0.86 & 132.0 \\
\hline $\mathrm{N}_{30} \mathrm{P}_{30} \mathrm{~K}_{30}$ locally & 2.71 & 3.48 & 3.47 & 3.22 & +0.53 & 119.7 \\
\hline $\begin{array}{l}\text { Inoculation with Ryzobofit } \\
+\end{array}$ & 2.53 & 3.45 & 3.45 & 3.14 & +0.45 & 116.7 \\
$\mathrm{P}_{30} \mathrm{~K}_{30}$ locally & 3.04 & 4.00 & 3.62 & 3.55 & +0.86 & 132.0 \\
\hline $\begin{array}{l}\text { Inoculation with Ryzohumin } \\
+\end{array}$ & 0.29 & 0.30 & 0.36 & & & \\
\hline $\mathrm{P}_{30} \mathrm{~K}_{30}$ locally & & & & & \\
\hline $\mathrm{LSD}_{05}$ & &
\end{tabular}


The activation of legume-rhyzobia symbiosis at using Ryzohumin based on R. phaseoli FB1 strain influenced bean quality. The content of starch in beans increased by $11.7 \%$ relative to control, total sugar - by $4.5 \%$ and ash content increased by $12.5 \%$ (during three years).

\section{Conclusions}

For pre-plant inoculation of grain bean and green bean seeds biological preparations Ryzobofit and Ryzohumin (peat form) based on a new highperformance strain of $R$. phaseoli FB1 were suggested. This strain is an active symbiotic nitrogen fixer, able to compete with local populations of bean rhizobia, increase plant resistance to root rot pathogens.

The use of biological preparations Ryzobofit and Ryzohumin based on R. phaseoli FB1 strain in different soil and climatic conditions contributes to stable increase in common bean yield relative to control by $11.0-32.0 \%$ and improvement in the quality of received products.

\section{References}

1. Agrojekologicheskaja rol' azotfiksirujushhih mikroorganizmov v allelopatii vysshih rastenij/V.F. Patyka [i dr.]; pod red. V.F. Patyki. - K.: Osnova, 2004. - $320 \mathrm{~s}$.

2. Bezugla O.M. Formuvannja oznakovyh ta special'nyh kolekcij kvasoli na Ukrai'ni/O.M. Bezugla//Selekcija i nasinnyctvo. - 2005. - Vyp. 9. - S. 309-317.

3. GOST 28561-90. Produkty pererabotki plodov i ovoshhej. Metody opredelenija suhih veshhestv ili vlagi.

4. Dospehov B.A. Metodika polevogo opyta/B.A. Dospehov. - M.: Agropromizdat, 1985. - $352 \mathrm{~s}$.

5. Kolotilov V.V. Genetychni resursy zernobobovyh kul'tur Ustymivs'koi'doslidnoi' stancii' roslynnyctva, rezul'taty ta perspektyvy rozvytku/V.V. Kolotilov, S.I. Sylenko//Selekcija i nasinnyctvo. - 2005. - Vyp. 90. S. 331-338.

6. Markova O.V., Garipova S.R. Otbor perspektivnyh linij fasoli (Phaseolus vulgaris L.) Sorta Jel'za i osobennosti ih simbiotrofnogo pitanija v raznyh pochvenno-klimaticheskih uslovijah Predural'ja/O.V. Markova, S.R. Garipova//Vestnik Bashkirskogo universiteta. - 2013. - T. 18, №3. - S. 709-712.

7. Metod vyznachennja cukriv M03-2001 [Tekst]/V.Ju. Goncharenko, T.K. Gorova, V.E. Barsukova; Instytut ovochivnyctva i bashtannyctva UAAN. Harkiv: IOB UAAN, 2006. - 8 s. 
8. Ermakov A.I. Metody biohimicheskogo issledovanija rastenij/A.I. Ermakov. - L.: Agropromizdat, 1972. - S. 107-109.

9. Krutylo D.V. Reakcija sortiv kvasoli na inokuljaciju Rhizobium phaseoli za najavnosti v g'runti chyslennoi' populjacii' ryzobij / D.V. Krutylo//Kormy i kormovyrobnyctvo. - 2008. - Vyp. 61. - S. 78-83.

10. Pat. 104211 Ukrai'na, MPK (2013.01) S 12 N 1/20, A 01 N 63/02. Shtam bakterij Rhizobium phaseoli dlja inokuljacii' sparzhevoi' kvasoli/Krutylo D.V., Nadkernychna O.V., Kovalevs'ka T.M.; zajavnyk ta patentovlasnyk In-t s.-g. mikrobiologii' ta agropromyslovogo vyrobnyctva NAAN. - № a 2012 03815; zajavl. 29.03.12; opubl. 10.01.14, Bjul. № 1. - 5 s.

11. Food and Agriculture Organization of the United Nations [Електронний pecypc]/Faostat, 2015.- Режим доступу: http://faostat3.fao.org/download/Q/QC/E.

12. Graham P.H., Vance C.P. Legumes: importance and constraints to greater use/P.H. Graham, C.P. Vance//Plant Physiol. - 2003. - № 131 (3). - P. 872-877. 